\title{
Jurisprudential principles of the cultural system of the Is- lamic Republic of Iran
}

\section{Principios jurisprudenciales del sistema cultural de la República Islámica del Irán}

\author{
Majid Sabzikaran \\ Jurisprudence and Fundamentals of Islamic Law, Islamic Azad University, Mashhad Branch, \\ Iran. \\ Gholam Hassan Delavar \\ Jurisprudence and Fundamentals of Islamic Law, Islamic Azad University, Mashhad Branch, \\ Iran. \\ Mohammad Reza Javaheri \\ Jurisprudence and Fundamentals of Islamic Law, Islamic Azad University, Mashhad Branch, \\ Iran.
}

*Correspondence

Email: hadijavadi18@gmail.com
Cite as:

\footnotetext{
Sabzikaran, M., Hassan Delavar, G., \& Reza Javaheri, M (2020). Jurisprudential principles of the cultural system of the Islamic Republic of Iran. Propósitos y Representaciones, 8 (SPE3), e764. Doi: http://dx.doi.org/10.20511/pyr2020.v8nSPE3.764
} 


\section{Summary}

Our revolution, unlike other movements and revolutions of the twentieth century, which often had economic and political foundations, was a cultural revolution, and we find carefully in the main slogans of the revolution (independence, freedom, republic and Islam) that Apart from the word "republic", which has a socio-political meaning, other slogans show the cultural foundations of this movement. Therefore, the cultural system of the Islamic Republic of Iran can be considered as the identity and manifestation of the Islamic Revolution. The set of right and wrong infrastructures is called the habitual beliefs and mental beliefs of a country and a nation called the cultural system. In this article, which has been written by descriptive-analytical method and library collection method and the use of Quran and authentic jurisprudential books, we have achieved the following results: The main basis of the cultural system of the Islamic Republic in the era of absence based on perspective He is a revolutionary provincial jurist and at the head of it is the architect of Imam Khomeini's revolution. The goals of the cultural system of the Islamic Republic of Iran are divided into short-term, medium-term, and long-term, the main purpose of which is to pay attention to the freedom of Muslims and to promote and export monotheism. The pillar of the cultural system is monotheism and its principles are the branches of religion and its sources are books, traditions, consensus, intellect and tools of the cultural system of seminaries, universities, education, media and artistic tools.

Keywords: Cultural System, Islamic Republic, Jurisprudence, Velayat-e-Faqih

Resumen

Nuestra revolución, a diferencia de otros movimientos y revoluciones del siglo XX, que a menudo tenían fundamentos económicos y políticos, fue una revolución cultural, y encontramos cuidadosamente en las principales consignas de la revolución (independencia, libertad, república e islam) que Aparte de la palabra "república", que tiene un significado sociopolítico, otras consignas muestran los fundamentos culturales de este movimiento. Por lo tanto, el sistema cultural de la República Islámica de Irán puede considerarse como la identidad y manifestación de la Revolución Islámica. El conjunto de infraestructuras correctas e incorrectas se llama las creencias habituales y las creencias mentales de un país y una nación llamado sistema cultural. En este artículo, que ha sido escrito mediante el método descriptivo-analítico y el método de colección bibliotecaria y el uso del Corán y de auténticos libros jurisprudenciales, hemos logrado los siguientes resultados: La base principal del sistema cultural de la República Islámica en la era de la ausencia. basado en la perspectiva Es un jurista provincial revolucionario y a la cabeza está el arquitecto de la revolución del Imam Jomeini. Los objetivos del sistema cultural de la República Islámica del Irán se dividen en corto, mediano y largo plazo, cuyo principal objetivo es prestar atención a la libertad de los musulmanes y promover y exportar el monoteísmo. El pilar del sistema cultural es el monoteísmo y sus principios son las ramas de la religión y sus fuentes son libros, tradiciones, consensos, intelecto y herramientas del sistema cultural de seminarios, universidades, educación, medios y herramientas artísticas.

Palabras clave: Sistema Cultural, República Islámica, Jurisprudencia, Velayat-e-Faqih 


\section{Introduction}

The cultural system of the Islamic Republic of Iran, although a unique and seemingly emerging phenomenon, but has the deepest and widest monotheistic beliefs that with a little care can be traced to the roots of this culture in human creation and even Found before. In a way that not only includes all cultures (both heavenly and earthly); Rather, it is a comprehensive culture for humanity until the Day of Judgment. So culture, like the thread of the rosary, is the connecting link of other communications and systems and puts the whole human being under its umbrella. Imam Khomeini (ra) says: "Western theorists explicitly acknowledge that secular culture also originated from Christianity, and if Christianity becomes obsolete, secular culture will also disappear" (Khosroshahi, 1396). Therefore, it can be said that the culture of the Islamic Republic is comprehensive for humanity. Culture is the showcase and symbol of a nation. In other words, it is the minds, ideals and desires of man that make up his culture.

History has experienced various systems and cultures, but the system of the Islamic Republic of Iran with the three terms "Republic, Twelve Islam and Iran" and in the words of the architect of the revolution (pure Muhammadan Islam) for the first time after 12 centuries has been able to make such an emergence. Have. All cultures, including Eastern and Western, the heavenly schools, and the culture of human schools, made by theorists, are in fact derived from the beliefs and attitudes that underlie cultures, but Shi'ism divides culture into right and wrong. He called the first the same light and straight path and has only one leader and path, and called the rest of the cultures darkness, whose leaders are numerous and whose ways are many and who has misled everyone. According to the Shiite view, the desired culture is to pave the way for the movement of the individual and society towards true perfection. For this reason, the architect of the revolution (ra) in the definition of culture says: "Culture is the source of all misery and happiness and what makes nations is the correct culture" (Sahifa, p. 36)

In this system, the laws are based on monotheism, nature and morality, which, unlike other non-religious systems, is based on scientific theories and perceptions and is based on the laws of the previous subject, or is the result of trial and error of the past and spirituality. Many ignore the fact that Muslims have established most of the laws according to the guidelines of their four leaders (Shafi'i, Hanbali, etc.) and therefore lack the living and dynamic spirit of ijtihad.

In a general and almost definite definition, it can be said that the set of right and wrong infrastructures of the belief and habitual mental beliefs of a country and a nation is called the cultural system. The cornerstone of other systems is the identity of a nation, its cultural system.

\section{Research background}

With the researches, no independent research has been done on the subject of the present research and this article is new and innovative in its kind. However, no research has been done on the jurisprudential principles of the Islamic Republic - in general - as well as the role and importance of culture in Islam and the holy system of the Islamic Republic, which are briefly mentioned.

Seyyed Sadegh Haghighat (2012) has made political jurisprudence and the theory of government the subject of his research and states that political jurisprudence and political philosophy are both valid and can help each other in the Islamic state. And with this view, it examines the relationship between jurisprudence and government (government). 
Also, Kamal Akbari (2012) in an article entitled "Capacities of political jurisprudence for systematization" acknowledges that Shiite political jurisprudence according to the internal capacities and needs, especially the experience of the Islamic Republic of Iran after the Islamic Revolution to design and Implemented a comprehensive socio-political system. Systematization in political jurisprudence that comes from the text and is completed by looking at the objective developments of the world and the needs of the religious community is something that started in the victory of the Islamic Revolution, but its completion, continuity and dynamism are ongoing.

Sadegh Salimi Bani (2013) has researched the "cultural situation of the Islamic Republic at the beginning of the fourth decade of the revolution" and examined its strengths, weaknesses, opportunities and threats.

Hamidreza Mir Azimi and Mohsen Jamshidi Kouhsari (2014) in a study on the "position of members of parliament in Islamic jurisprudence with emphasis on the ideas of Imam Khomeini (ra)" and with the title that some believe in the application of the concept of parliamentary representation in the sharia and in On the contrary, some reject this adaptation for many reasons, showing that Imam Khomeini as a jurist and the founder of the system, although many times from the representative

That parliament interpreted the nation's lawyers, but what can be deduced from all his words is that the nation's lawyers were referred to the parliament members based on the literal meaning of advocacy and development in it and not the conformity of the concept of advocacy in jurisprudence with parliament representation.

Ashraf Boroujerdi (2015) in an article "The role of socio-cultural policies in the general policies of the system, upstream documents and program laws in the Islamic Republic of Iran" reviewed and showed that the share of social and cultural issues In the macro policies of Iranian society, it does not have the necessary coordination with social and cultural developments.

Mohammad Ismail Nabatian (2016) in an article entitled "Jurisprudential principles of the Islamic Republic; The political security of the Islamic system from the perspective of Shiite jurisprudence has examined the issue of security and, in particular, political security in the system of the Islamic Republic and from the perspective of jurisprudential principles.

In his book, Gholamreza Siddiq Orei examines the structure of the social system in Islam and analyzes a set of social, political, economic, as well as cultural and educational systems of Islam.

Mohammad Javad Arista in a book entitled "A Look at the Analytical Foundations of the Islamic Republic of Iran; Reflections on Political Jurisprudence and the Jurisprudential Principles of the Constitution of the Islamic Republic of Iran " Has dealt with jurisprudence and legal standards.

Ayatollah Abbas Kaabi has also analyzed the fourth principle of the constitution in his book "Analytical Foundations of the Islamic Republic of Iran". This principle states that all civil, criminal, financial, economic, administrative, cultural, military, political, etc. laws and regulations must be in accordance with Islamic standards. Therefore, in this book, the jurisprudential principles of the mentioned principle have been studied and analyzed.

Kamal Akbari in a book entitled "Political Jurisprudence and the Islamic Republic of Iran" has described the interactive effect of political jurisprudence and the Islamic Republic in a 
descriptive-comparative manner. He had previously written books such as Political Jurisprudence and the Islamic Republic of Iran, The Evolution of Shiite Political Jurisprudence, Legitimacy and Political Participation in the Islamic Republic of Iran, The Course of Social Developments in the West, etc. In this book, the wider form of his doctoral dissertation It raises the question of what effect the developments of the first decade of the Islamic Revolution and the formation of the Islamic Republic have had on Shiite political jurisprudence, given the formation of the Islamic Republic of Iran based on Shiite political jurisprudence and the theory of Velayat-e Faqih. To what extent are the policies in the Islamic Republic of Iran based on political jurisprudence and what has been the basis for examining the centers of influence of political jurisprudence and the Islamic Republic?

The sum of researches in studies and researches shows that no research has been done on the subject of the present article so far and therefore the importance and necessity of addressing this issue is felt more than before.

Therefore, in the following, we first study the concepts and then study the foundations of the cultural system, its goals, characteristics, pillars, principles, resources and tools.

\section{Concepts and terms}

\section{Fiqh}

Jurisprudence in the word means to know and understand and in the term it also means to understand hidden things (Andisheh Qom website, 2016, p. 14).

Jurisprudence has been used in the absolute sense of understanding and knowledge, knowing something, understanding it, knowing, realizing from the present information to the missing information.

\section{Cultural system}

A system is a set with related and at the same time purposeful components, so a system, while being purposeful, has interconnected components and elements that are related to each other.

The set of right and wrong infrastructures of a belief attitude and the habitual mental beliefs of a country and a nation is called the cultural system. According to the definition of system, social phenomena, groups and human communities are considered as "system"; That is, human groups and communities are collections that are composed of interconnected elements, relatively harmonious and have a collective work and effect. But in the sociological literature, the social system is: "a set of social situations related to each other along with social roles and bases" (Orei, 2003, p. 17).

In this research, the system does not mean its sociological concept, but it means a set of common elements and based on special principles that have a collective effect and function. In this article, whenever we talk about the system, culture and Islam, we mean the intellectual system of its architect, Imam Khomeini, who referred to it as "pure Islam."

\section{Types of systems}


Systems are divided in form, sovereignty, vision, economic and political into divisions such as republic, socialist, monarchy, democracy, dictatorship, liberal, secular and fundamental, each of which has its own rules and regulations. On the other hand, a system may be modeled on the United States, Britain, and the former Soviet Union, and subordinate militaries such as China and Korea. The cornerstone of systems in divisions depends on the culture and beliefs of each country and nation.

\section{IR}

In this system, the basis of laws is based on monotheism, nature and moral virtue, which, unlike other secular systems or based on scientific theories and perceptions and is based on the laws of the previous subject in the progressive and cultural system of pure Islam, correctness of practice and custom. It must be subject to the right, not the will of the majority, because the view of the majority is not only incomplete and incomplete, but because of its low utility, it leads to conflict and instability in the long run. Achieving stability is possible when it is the manifestation of truth and truth, in other words, it is a desirable custom of religion that does not contradict the Shari'a and is only "famous", because it is not specific to the action, but is general and includes words and intentions. Becomes. In the Imamite school, it includes everything whose goodness has been proven by the Shari'a or common sense (infallible).

In the discourse of the founder of the revolution, the republic is a form of political system that reflects the thinking of contemporary Islamism.

The prominent point in the republic is the presence of Velayat-e Faqih along with other institutions, which has led to the formation of a special type of government in Iran (Khosrow Panah, 1396, p. 14).

Imam says: "I vote for the Islamic Republic, not one word more, not one word less." The form and system of this government is the "Islamic Republic". The word "republic" defines the form of government and the word "Islamic" defines its content. A republic requires a kind of democracy; That is, the people have the right to take control of their own destiny, and with this word, some types of governments, such as hereditary, monarchical, etc., are denied, but "republic" does not mean that the people themselves are inclined to ideology and "They should exempt a school." The word "Islamic" refers to the government being governed by Islamic law. Some minorities, with particular views, wanted to remove the word "Islamic"; Under the pretext that there is absolute sovereignty so that they can later object to the Twelver Laws (Sahifa Imam, pp. 324-328).

\section{Fundamentals of the cultural system}

Carefully looking at the verses and hadiths and following the biography of the heavenly prophets, we find that the basis of the movement is all based on monotheism within the framework of Islamic ideology and following its progressive laws and rules, although these commands and regulations at any time compared to The understanding and need of that time has been revealed. Accordingly, the main basis of the cultural system of the Islamic Republic in the era of absence is based on the view of the revolutionary provincial jurists and at the head of it is the architect of the revolution, Imam Khomeini. His most important intention was to form a government in the age of occultation, which he considered based on the theory of the absolute authority of the jurisprudent and believed that Islam has the power to manage the affairs of the international community and if we consider his happiness as the most central basis of human 
thought and desire. To achieve it, we will not achieve this important except by following the life-giving school of Muhammadan Islam - pure Islam - and loving and following the pure Imams (AS). The books of Velayat-e-Faqih, the explanation of forty hadiths and their writing are full of verses, narrations and rational and logical arguments around this theory.

\section{Objectives of the cultural system}

Every being emerges for a purpose or purposes. It is safe to say that "God also has a purpose in creation." When you ask the Almighty why you created, he says: "You were secretly amazed at my knowledge" (Encyclopedia of the Prophetic Hadith, p. 507) I wanted to be known. For the second time, when you ask, he says: "The creation of the jinn and mankind is nothing but worship (Dhariyat: 56). Indeed, We did not create the jinn Vance except for worship and obedience (theology and self-knowledge). The third time you ask, the answer is: "I created everything for you and I created you" (in the presence of Behjat, p. 37) I created everything for you and you for myself, based on this, the cultural system of the Islamic Republic is also based on this issue. It is no exception and has a purpose and goals. I did not find a word more eloquent than the words of the architect of the revolution who said: "Our whole destination is our school" (Imam Khomeini Sahifa, p. 76). But the sub-goals of the system are divided into three parts: short-term, medium-term and long-term. In the first, it seeks immediate policies and decisions to solve the problems of the country and the nation in relation to the current situation. The second goal is to establish the system in the shadow of legislation and the rule of law of individuals in order to achieve the next goals. The long-term goal of this system is to look at scientific progress and achieve full independence in all fields in order to communicate with the international community, especially paying attention to Muslims and freedom-seekers, and to promote and export monotheism.

In order to move towards the goals, it is necessary to first examine four issues: "Where we have been, where we are, where we will go and how we should go." If one does not know where he is and where he is, where he intends to go and where he is going, he neither knows the goal nor has the motivation to go and will never reach the destination.

\section{Characteristics of the cultural system}

1) Formation of the constitution with a cultural approach

Following the successive failures of the Muslim and revolutionary nation in past movements such as the nationalization of oil, the uprising of the forest and the repression and isolation of the constitutional movement, the architect of the revolution and its original nuclei thought of passing a law on the morning of February 14, 1957. By implementing it, while cutting the hands of foreigners, they should prepare the ground for the establishment of Islamic rules and regulations in all matters, and at the same time, the administration of affairs should be in the hands of the people, so that the slogan "Independence, Freedom, Islamic Republic" can be used as soon as possible. Be legally realized. Imam's determination and repeated attention to the preparation, compilation and approval of the constitution caused various delegations to draft it.

2) Assembly of Experts 
The Assembly of Leadership Experts is a assembly composed of qualified jurists who, according to Article 107 of the Constitution of the Islamic Republic of Iran, have the responsibility of appointing the Supreme Leader (Leader of the Islamic Republic). The term of each of these members, whose members are elected by direct and secret ballot, is eight years.

\section{3) Islamic Consultative Assembly}

Since the legislature in a country is the Shura Council, there is no doubt that the necessity of the law and the continuous developments of social life and international relations and the resolution of conflicts in them is the work of the legislature. Even in the cultural system of the Islamic Republic, despite the comprehensive divine laws, it is necessary to have an institution that, while applying global rules to religion, formulates new issues and secondary rulings in the needs of the country and nation as a law so that it does not run into problems. Of the Islamic Consultative Assembly).

\section{4) Expediency Council}

In the constitution, legislation was the responsibility of the Shura Council and monitoring and recognizing the inconsistency or non-inconsistency of laws with the norms of Sharia and the Constitution with the Guardian Council, and the Majlis was required to

Roy was not envisaged by the Guardian Council as a reference for resolving disputes between the two institutions (Constitutional Law of the Islamic Republic, p. 734). Due to the parliament's efforts to pass laws and some of the repeated objections of the Guardian Council and the parliament's insistence on the need to pass these laws, the two institutions faced each other. As a result, based on expediency and necessity, it was necessary to form an institution to resolve disputes in these cases, and with the recognition of some representatives and some high officials, they asked the Imam to form an expediency council, which was finally approved by the architect of the revolution.

\section{5) Foundation of the Oppressed}

Supporting the deprived and the poor is one of the high teachings of Islam to the extent that it has always been considered by the fourteen infallibles. The Prophet (pbuh) said in a hadith: "Seek me among the weak, because you are provided for by the weak people who provide for you and help you" (Keys Acts / 6019) and in another place: "Indeed, God has led this nation through prayer. And prayer and sincerity help the weak "(Al-Dar Al-Manthur, 2/724).

Attention to the weak strata shows the special attention that the Imam paid to the oppressed and deprived classes of society before the victory of the revolution, which showed the orientation of the masses of political Islam and jurisprudence. Imam called on the intellectuals to use their pen and speech in the service of the oppressed, so much so that he proposed the establishment of a party of the oppressed in the world: "I hope that a party called the oppressed will be established all over the world and all the oppressed will be together. Let this party participate and eliminate the problems that are in their way, and rise up against the arrogant and predators of the East and the West, and no longer allow the arrogant to oppress the oppressed of the world, and fulfill the call and promise of Islam that the rule of the oppressed is over the arrogant and inherit the land. For the oppressed, let them realize "(Sahifa Imam Khomeini, vol. 9, p. 280).

6) Councils 
Since the principle of the system is Islam and the second principle of the republic, in the republic, all the affairs of the country are based on public votes and councils such as the Shura Council, the city council, the Expediency Council, the Assembly of Experts, the Supreme National Security Council. In numerous verses and hadiths and in authentic Shiite and Sunni books, I see many cases in which the principle of the council is emphasized in various forms and interpretations, and self-determination and self-centeredness are strictly forbidden (Abi Dawood, Bab Adab, 114; Sind Ahmad Ibn Hanbal, 5 / 274-13). The Almighty God also emphasizes the necessity of deliberation and says: "People with faith and merit are those who have responded to the call of truth ... and put their affairs among themselves with passion and resolve" (Shura, p.38).

\section{7) Basij}

Basij is one of the blessings of the cultural system and one of the most valuable documents of the commitment of the Iranian people to support the Islamic Republic, because it is an institution that has boiled from the hearts of the people and after Qal al-Baqir and Qal al-Sadiq (AS) is the strongest supporter of the system. Comprehensive internal security of the country's borders. The formation of the Basij is from God Almighty, who has given this noble lineage to the people and the Islamic Revolution.

\section{The pillars of the cultural system}

The main pillar of the cultural system is monotheism. But it must be realized that having pure certainty about something has no real value and is not called faith, and requires practical certainty to it, and adherence to it in all circumstances, and one should not act contrary to it. The narrator of "La ilaha illa Allah" is a believer if he does not follow any other law in his life other than the divine law and does not seek refuge in other than him to solve his problems and does not call on other than God for help.

After accepting the monotheism of Versailles, it has been narrated in reliable and consecutive narrations that when the pious Mawlawi Ali (AS) was struck in the altar, a voice arose from the sky on the theme of. That is, with the blow of Ali (AS), the pillars of religion collapsed. This narration states that "Imamate" and the guardianship of the Imams (AS) are among the pillars of religion. On this basis, based on the interpretation of some verses and narrations, the pillars of the Islamic Republic are divided into two types, cultural and physical.

A- Cultural: which after the book and tradition, the constitution is in the age of absence.

B- Physical: The existence of prophets, saints and jurists with special conditions.

Therefore, two branches of descriptive (from God) and legal credit (from the innocent) are the pillars of our system. The most important pillars of any society are the institutionalization of the rule of law and its legal institutions.

\section{Resources of the cultural system}

The cultural system of the Islamic Republic of Iran is derived from the book, tradition, consensus and reason.

A- Book: All scholars have considered the revelation of the Qur'an on the Seal of the Prophets as the greatest miracle and event of the universe because its words and letters are all from God 
and unlike other divine books, it has been revealed beyond human manipulation and distortion and according to the saying. The greatest feature of this book is that during the revelation, recording and recording it with the direct guarantee of the Supreme Being is safe from any interference and manipulation.

B- Tradition: In the word, it means method and method and is used against heresy. In Shiite terms, Sunnah is considered to be the word and narration of the Infallible (PBUH) and the Infallible Prophet (PBUH) means the Twelve Imams and Fatemeh Zahra (PBUH). The words and narrations of the fourteen infallibles (AS) are Sunni and authentic according to the Shiites (Feyz, 2016, p. 27).

C-Consensus: Consensus is the word of determination and intention and coincidence, and in the term from the Shiite point of view, it is the consensus of those whose words are valid among the ummah; Of course, provided that the discoverer is from the word of the Infallible (AS), it means that the word of the Infallible Imam must be among them (Feyz, 2016, p. 35).

D. Reason: The fourth source of the cultural system is rational reason. Of course, some people consider it as a book and a tradition, and some as a book and a tradition. Because actions, regardless of the ruling of the Shari'a, have intrinsic value (good and bad) and the intellect can understand it.

\section{Principles of the cultural system}

After the five principles - monotheism, justice, prophethood, Imamate and resurrection - the ten branches of the Jafari school, which is called the "branches of religion", are other principles. It is the system of the Islamic Republic that is in fact complementary to the principles of religion. While explaining and expanding the principles, these branches have included all the unknowns and human needs according to the narrations of the Imams (AS) and the ijtihad of the jurists until the Day of Resurrection. With the efforts of mujtahids and jurists at any time, the key to these unknowns and meeting the needs of society can be achieved.

The comprehensiveness of the Twelver culture is due to the fact that it is not a special school for a limited time and people, its learning over time, place and any circumstances is an advantage that is specific to pure Islam. The characteristic of survival and evolution according to this worldview is the distinction of this culture which is monotheism, the law of the Prophet and love and obedience to the appointments of His Holiness (Ahl al-Bayt (AS)) which is the greatest weight and the strongest thread in the relationship between man and God. And is human.

Another difference between the Ja'fari school and other Islamic religions is the attainment of the source of true knowledge and tranquility, which can only be achieved through love for the family of Muhammad. (Shura: 23). Also, "the word of God is not strong except for those who say that they enter the stronghold and from the entrance of the stronghold is safe from torment" (Baharalanvar, $1403 \mathrm{AH}$, p. 123).

\section{Tools of the cultural system}

In general, the cultural tools of a system can be all the options used to induce the message and through which the message can be conveyed to the audience. These tools have different hierarchies and degrees of importance, of which seminaries, universities, education, virtual media and cultural and artistic institutions are the most important tools of our cultural system. 


\section{Discussion and Conclusion}

The importance and position of culture as the foundation and showcase of the whole view of the cultural system of the Islamic Republic is also included. In this article, only the subject of the cultural system of the Islamic Republic from the intellectual system of its architect Imam Khomeini has been focused and tried. Taking from the Qur'an, the narrations of the Infallibles (AS), the collection of works of the Imam (AS) from 1941 and his other sincere companions such as the Supreme Leader and the martyrs, which is taken from the Alawite and Fatimid culture, the general lines of the cultural system should be extracted and analyzed.

Every phenomenon, system and event in existence is the result of thought and instrument, and in other words, existence consists of soul and body, of which the Islamic Republic is no exception. The thought and cultural spirit of the Islamic Republic system is in accordance with the noble verse of "John the Baptist" from the body of transcendence and its body from the infallible (Ana Bashar Mathlkum) and the cultural basis of the system is based on the book, tradition, consensus and reason. All cultures are based on beliefs, attitudes and habits, and human-centeredness is the second common denominator of all cultures. The culture of the Islamic Republic is unique (Alawite) and for this reason it is compared to light in the Qur'an and is called the straight path and the centrality of man in this system is based on monotheistic belief.

The foundations of the cultural system of the Islamic Republic of Iran have been in the framework of Islamic ideology and following the progressive laws and rules, which are taken from the verses of the Holy Quran and the narrations of the Prophet (PBUH) and his pure family. Laws and regulations have always been revealed in accordance with the understanding and needs of that time, and based on this, the basis of the cultural system of the Islamic Republic in the era of absence is based on the view of the revolutionary provincial jurists and at the top is the founder of Imam Khomeini's revolution.

On the other hand, considering that nothing in the world of creation is aimless and God also had goals from the creation of man, therefore the cultural system of the Islamic Republic of Iran also has goals that fall into three categories: short-term, medium-term, and long-term. It is divided and its purpose is to promote and issue monotheism and pay more attention to the freedom of Muslims. Also, the cultural system of the Islamic Republic has indicators such as: the Constitution, the Assembly of Experts, the Guardian Council, the Islamic Consultative Assembly and the Expediency Council, etc. The pillar of the cultural system of the Islamic Republic of Iran is monotheism and its sources are books, tradition, consensus and reason. After the five principles - monotheism, justice, prophecy, Imamate and resurrection - the ten branches of the Ja'fari school, which are called "branches of religion", are other principles of our system that are in fact complementary to the principles of religion and its tools are seminaries, Universities, education, media and art tools.

According to the above, we find that the basis of the cultural system of the Islamic Republic of Iran originates entirely from the Qur'an, Islam and hadiths and is considered the best cultural system and according to Imam Khomeini (ra): Islam is the power to manage affairs. It has a world community, and if we consider human happiness as the most central basis of human thought and desire and seek to achieve it, except by following the life-giving school 
of Muhammadan Islam - pure Islam - and loving and following the pure Imams (AS) to We will not achieve this important.

\section{References}

Ashouri, Dariush, Definitions and Concepts of Culture, Tehran, Agha Publishing, Seventh Edition, 1397.

Orei, Gholamreza, A Study of the Structure of the Social System in Islam, Tehran, Radio and Television, 2003.

Arista. Mohammad Javad, the concept of application in Velayat-e-Faqih. Baqer al-Uloom Education Institute. Qom, 1998

Ibn Manzoor Masri, Jamal al-Din Muhammad ibn Makram, Arabic language, first edition, Beirut, Dar al-Fikr, 1410 AH.

Free agent, Mohammad Ibn Hassan, Shiite means to study Sharia issues, sixth edition, Tehran, Islamic School, $1403 \mathrm{AH}$.

Khosropanah. Abdolhossein, Imam's intellectual system. Farhang Research Institute Publications, 2017

Khomeini, Seyyed Ruhollah, Tahrir al-Wasila, fourth edition, Tehran, Maktab al-Etemadi, 1403 AH.

Khomeini, Ruhollah, Sahifa Noor, Tehran, Ministry of Culture and Islamic Guidance, Organization of Cultural Documents of the Islamic Revolution, 1991.

Dehkhoda, Ali Akbar, Dictionary, Institute of Printing and Publishing, University of Tehran, Tehran, 1993

Saduq, Muhammad ibn Ali ibn al-Husayn ibn Babawiyyah, I do not attend the jurisprudent, third edition, Qom, Qom Seminary Teachers Association, 1413 AH.

Tabatabai, Seyyed Mohammad Hussein, Al-Mizan Fi Tafsir Al-Quran, translated by Mohammad Baqir Mousavi Hamedani, Qom, your office Islamic Sharat, fifth edition, 1995.

Feyz, Alireza, Principles of Jurisprudence and Principles, University Press, 24th edition, 2016

Klini, Mohammad Ibn Yaqub, Al-Kafi, fourth edition, Tehran, Islamic Library, 1986.

Mottaqi Hindi, Aladdin, Kanz al-Amal, Al-Risalah Institute, Beirut, 1409 AH

Majlisi, Mohammad Baqir, Baharalanvar, third edition, Beirut, Al-Wafa Institute, 1403 AH.

Moin, Mohammad, Farhang-e Farsi, Sepehr Publications, Tehran, 1981

Motahari, Morteza, Collection of works, first edition, Tehran, Sadra, 1990.

Motahari, Morteza, Islam and the Problems of Time, Tehran, Sadra Publications, Bita .. 
Najafi, Mohammad Hassan, Jawaher al-Kalam fi Sharh Sharia al-Islam, third edition, Tehran, Islamic Library, 1988. 